\title{
KEELE UUENDAMISE PIIRID JA ANALOOGIA ${ }^{1}$
}

\author{
MARTIN EHALA
}

\begin{abstract}
Annotatsioon. Artiklis analüüsitakse Johannes Aaviku keeleuuenduse näitel, kas keele teadlikul uuendamisel on keele ehitusest tingitud piire ja kas ebaõnnestunud uuenduste põhjal on midagi võimalik öelda selle kohta, millised muutused keeles üleüldse võimalikud on. Traditsiooniliselt on ajaloolises keeleteaduses levinud seisukoht, et keele struktuuri mõjutavaid uuendusi ei ole võimalik tahtlikult esile kutsuda. Viimase poole sajandi jooksul on see seisukoht seatud kahtluse alla, esitatud on näiteid vastupidise kohta, kaasa arvatud Aaviku keeleuuendus. Lähtudes Royal Skouseni analoogilise modelleerimise mudelist, esitab artikkel hüpoteesi, et selliseid konstruktsioone, millel ei ole keeles analoogiamalli, ei ole võimalik keelde juurutada. Väite kontrollimiseks analüüsitakse Aaviku jt edukaid uuendusi ning tuuakse esile, et kõigil neil on eesti keeles olemas selge analoogiamall. Hüpoteesi toetab ka asjaolu, et mõnel Aaviku ebaõnnestunud uuendusel, nagu nue-, tue-vormidel ja no-genitiivil, sobiv analoogiamall puudub. Küsimusele, kas analoogia puudumine on absoluutne piirang keelemuutuse võimalikkusele, ei saa analüüsitud materjali piiratuse tõttu siiski lõplikult vastata.
\end{abstract}

Võtmesõnad: keeleuuendus, keelemuutuse piirangud, analoogia

\section{Sissejuhatus}

Keeleuuendus on tahtlik keelemuutus. Teoreetilises ajaloolises keeleteaduses on üldlevinud arvamus, et tahtlikud keelemuutused on oma olemuselt lihtsakoelised: välja mõelda võib küll uusi sõnu, kuid keerulisemad manipulatsioonid keelega jäävad inimese juhtivale käele kättesaamatuks. Näiteks keele grammatilist struktuuri muutvaid uuendusi ei ole põhimõtteliselt võimalik tahtlikult algatada.

${ }^{1}$ Artikkel põhineb Huno Rätsepa juubelikonverentsil 28.12.2012 peetud ettekandel ja on valminud sihtfinantseeritava teadusteema SF0180084s08 „Eesti keele morfosüntaktiline ehitus ja areng" raames. 
Need, kes on tuttavad Aaviku keeleuuendusega, võivad viimase väite küll kahtluse alla seada. Olgu selleks lühike sisseütlev, vokaalkujuline mitmuse osastav ja mitmuse tüvi või sünteetiline ülivõrde vorm - kahtlemata on tegu uuendustega, mis muutsid eesti keele morfoloogiat, ning kahtlemata on tegu uuendustega, mis ei oleks ilma Aaviku pingutusteta keelemuutuseks kujunenud. See näitab, et tahtlikud keelemuutused võivad olla ka üsna keerukad.

Seega võib väita, et küsimus, kui keerukaid muutusi on inimese tahtel võimalik keelde juurutada, ei ole kaugeltki lõplikult vastatud. Kindlasti on inimese võimalused oma keelt mõjutada suuremad, kui üldiselt arvatud, kuid päris täpset vastust selle kohta, kus on keele uuendamise piirid, antud veel ei ole. Põhimõtteliselt on see küsimus osa laiemast probleemist, millised on üldse keele uuenemise piirid. Kas keel võib oma isearenemise käigus muutuda milliseks tahes või on ees mingid piirid? Sellele küsimusele on raske vastata, sest loomulik keele areng ei paku meile materjali ebaõnnestunud keelemuutuste kohta, st kõik, mis juhtub, on võimalik, aga see, mida pole juhtunud, selle kohta me ei tea, kas see on lihtsalt juhus või ei saagi sellised muutused toimuda. Keeleuuendus on selle avarama küsimuse lahendamiseks suhteliselt tänuväärne valdkond. Võib ju keeleuuendust vaadelda kui keeleteaduslikku eksperimenti, mis suudab anda vastuse mõningate keelemuutuste võimalikkuse ja võimatuse kohta.

Artikkel püüab Johannes Aaviku keeleuuenduse näitel veidi analüüsida mõlema küsimuse olemust: esiteks, kas keele teadlikul uuendamisel on mingeid strukturaalseid, keele ehitusest tingitud piire, ja kui jah, siis millised need on; teiseks, kas ebaõnnestunud uuenduste põhjal on midagi võimalik öelda selle kohta, millised muutused keeles üleüldse võimalikud on, st kus on keelemuutuse piirid.

\section{Varasemad käsitlused}

Vastus küsimusele, milliseid muutusi inimene keelde võib tuua ja milliseid mitte, või siis laiemalt, millised muutused on üleüldse võimalikud, oleneb paljuski sellest, milline on meie ettekujutus keele olemusest. Võtame näiteks küsimuse, kas grammatika on olemas või on see ainult keeleteadlaste uurimistöö üldistav kokkuvõte. Kui usume, et grammatika eksisteerib ka tegelikkuses, siis järgmine kiuslik küsimus, mis kohe üles kerkib, puudutab tema olemise vormi. Põhimõtteliselt tuleb valik teha 
kolme puhta ontoloogia vahel: keel on füüsikaline nähtus nagu linnud, lilled ja liblikad; keel on psüühiline nähtus nagu mõtted ja tunded; keel on abstraktne nähtus nagu matemaatika- ja loogikareeglid. Võib ka valida nendest mingi kombinatsiooni.

Ilmselgelt on keel vähemalt osaliselt füüsikaline nähtus: kõne on kuuldav, kiri on loetav, need mõlemad on empiiriliselt tajutavad reaalselt eksisteerivad füüsikalised nähtused - häälelained või tindijäljed paberil. Samas on täiesti kindel, et grammatikareeglid ei eksisteeri sarnasel viisil. Reegleid on kõige kergem mõista kui kõnetegevust reguleerivaid seaduspärasusi. Sellest lähtudes on keelt ja grammatikat püütud mõista kui psühholoogilist nähtust, selle lähenemise kõige kuulsam esindaja on kindlasti Noam Chomsky.

Tema vaadete kohaselt ei eksisteeri grammatika kuskil mujal kui keelekõnelejate teadvuses, kust see põlvkond põlvkonna järel kopeeritakse üha uute keelekasutajate teadvusse (Chomsky järgi on ka osa grammatikast kaasa sündinud). Selle vaate kohaselt on keele muutus põhimõtteliselt viga, mis tekib keeleomandamise protsessis, kui lapsed teevad vanemate keelelise käitumise järgi grammatilise struktuuri kohta valejäreldusi. Selle seisukoha järgi on täiskasvanu võimetu muutma oma grammatikat, välja arvatud mõne üksiku reegli lisamine või unustamine (vt näiteks Chomsky, Halle 1968; Lightfoot 1991; Labov 1994). Päris kindlasti ei ole chomskyliku keelekäsitluse puhul mõeldav, et üksikisik saaks põhjustada mingi suuremat sorti muutuse keele struktuuris, sest see eeldaks süstemaatilist üleriigilist drilli lastesõime asukatega.

Samuti oleks keelemuutus täiesti mõeldamatu juhul, kui tegemist oleks samasuguse abstraktse süsteemiga nagu matemaatika- või loogikareeglid. Viimaseid iseloomustab see, et nad on täiesti staatilised. Võib ju olla, et inimesed ei ole kõiki formaalse loogika või matemaatikareegleid veel avastanud, kuid need, mis on avastatud, ei ole aegade jooksul läbi teinud kõige vähematki muutust. Kui keel oleks samasugune süsteem, siis oleks inimkonnal kõige tõenäolisemalt vaid üks keel, mis suudaks küll väljendada kõike olemasolevat, kuid mitte midagi põhimõtteliselt uut, ning sobiks tunnete väljendamiseks umbes sama hästi kui matemaatika. Õnneks see nii ei ole ja see tähendab, et keele ontoloogia on palju keerukam kui üks nendest kolmest puhtast olemisvormist.

Päris kindlasti on keelel sotsiaalne dimensioon. Seda valdkonda esindavad näiteks Ferdinand de Saussure ja Edward Sapir. Mõlema ontoloogilised 
seisukohad on raskesti määratletavad. Saussure'i järgi on keel midagi, milles igal keelekõnelejal on osa, aga mis on terviklik ainult kogu keeleühiskonnas - mida see avaldus tähendab ontoloogiliselt, sellest on raske aru saada. Sapiri jaoks on keel kultuuriline nähtus, seega õpitud, mitte loomulik (nagu hingamine). Mõlema jaoks on keelemuutus midagi, mis kulgeb keelekasutajast sõltumatult. Sapir (1921) ütleb otsesõnu, et keelemuutuses osaleja ei ole mitte toimija, vaid ohver. Arusaadavalt ei ole sellise lähenemise korral võimalik seletada, kuidas näiteks Aaviku keeleuuendus üleüldse saanuks võimalik olla. Seega vajab keelemuutuse põhjalikum mõistmine veel veidi dünaamilisemat arusaama keelelistest protsessidest, sellist, mis eeldab ka keelekasutaja mõnesugust aktiivset osalust.

Kõige kergem on sellist ontoloogiat ehk ette kujutada Karl R. Popperi (1972) objektiivse teadmise mõiste abil. Popperi järgi on näiteks teaduslikud teooriad objektiivsed nähtused, kuigi need on loonud üksikud teadlased, kes on selleks kasutanud oma kognitiivseid võimeid, kaasa arvatud keelt. Kuigi teooriat luuakse ja täiendatakse individuaalselt, on teooria sisu inimestevaheline - ta on sõltumatu selle arendajate psüühikast ning ta tõesus ei sõltu tema loojate vaimsest seisundist. Philip Carr (1990) on sellist arusaama rakendanud keele suhtes ning väitnud, et ka keele reeglid, laused ja märgid on kõneleja teadvusest sõltumatud, kuid temaga siiski suhestatud. Selline vaatenurk sobib hästi keelemuutuse seletamiseks: kõnelejaskonna poolt pidevalt toodetud lausungid moodustavad dünaamilise korpuse, mille põhjal needsamad keelekasutajad kujundavad oma individuaalse grammatika, samas oma keelekasutusega panustades sellessesamasse korpusesse. Sellise vaatenurga kohaselt on grammatikat defineerivaks materjaliks pidev reaalajas muutuv korpus, muutuse algatajaks aga üksikisiku panus sellesse korpusesse (vt Ehala 1996a, 1996b).

Üsna lähedast arusaama keelemuutusest esindab ka Sarah Thomason, kes on üks vähestest, kes viimastel aastatel on tahtliku keelemuutuse problemaatikaga tegelenud. Oma artiklis (Thomason 2007: 45) ütleb ta, et „küsimus keelemuutuse lingvistilisest võimalikkusest - kui tegu on tahtliku muutusega - saab lahenduse niipea, kui esimene kõneleja toob kuuldavale esimese lausungi, mis seda muutust iseloomustab. Kas see teadlik keelemuutus saab püsivaks osaks selle kõneleja idiolektist või kogu keelekogukonna jagatud grammatikast, on lihtsalt sotsiaalse ja keelelise tõenäosuse, mitte võimalikkuse küsimus"2. Seega, Thomasoni

\footnotetext{
2 Martin Ehala tõlge.
} 
seisukoht on, et kui keelekõneleja on põhimõtteliselt võimeline teatud konstruktsiooni oma lausungis kasutama, siis on keelemuutus, mis selle konstruktsiooni keeles põlistab, põhimõtteliselt võimalik, kui tingimused selle levimiseks on soodsad. Selle seisukoha järgi on seega teoreetiliselt peaaegu kõik võimalik, aga tegelikkuses jääb palju toimumata lihtsalt seetõttu, et muutus ei lähe läbi.

Sarah Thomason (2007) püüab avada ka tahtlike keelemuutuste põhjuseid ja esitab ka rea näiteid nende kohta. Suurem osa tema näiteid puudutab juhtumeid, kus tahtliku keelemuutuse tagajärjel suurenes keeleline eristumine mõnest lähisugulaskeelest. Näiteks Tansaanias kõneldav $m a$ ' $a$ keel on viimase paari sajandiga oluliselt bantustunud, nii et järele on jäänud üsna vähe algupäraseid kuši jooni. Üks selliseid on helitu lateraalne frikatiiv, mida bantu keeltes ei esine ja mida bantud peavad väga raskesti hääldatavaks. Et suurendada $m a$ ' $a$ keele eristumist bantu keelest, on ma'a kõnelejad tahtlikult hakanud seda häälikut kasutama ka bantu keelest laenatud sõnades.

Üsna radikaalne on ka keelemuutus, mille viisid ellu usai keele kõnelejad. Thomason (2007) kirjeldab varasematele allikatele toetudes (Laycock 1982; Kulick 1992), kuidas selle keele 1500 kõnelejat Bougainville'i saarel Paapua Uus-Guineas olid mures, et nende keel on liiga sarnane lähisugulaskeele buiniga, mida naabersaartel kõneleb umbes 17000 inimest. Et sarnasust vähendada, vahetasid usai keele kõnelejad ära anafoorset ühildumist markeerivad meessoo ja naissoo lõpud, nii et need toimisid peegelpildis buini keele samade markeritega.

Sarah Thomason toob Els Oksaare andmetele (Oksaar 1972) toetudes näiteks ka Aaviku keeleuuenduse, mainides sünteetilist ülivõrret ja neologisme, kuid ei analüüsi neid muutusi pikemalt (Thomason 2007). Ta vaid märgib, et Aaviku keeleuuendus ilmselgelt ei sobi üldlevinud ettekujutusse, et vähegi sügavamad tahtlikud keelemuutused on põhimõtteliselt võimatud. Aaviku keeleuuendus on seda tähelepanuväärsem, et see oli motiveeritud põhiliselt esteetilistest kaalutlustest ja keelekontaktid ei mänginud uute muutuste juurdumisel mingit rolli.

Eesti keeleteadlastest on tahtlike keelemuutustega kõige põhjalikumalt tegelenud Valter Tauli (1974) ja tema hinnangul ,ei ole teoreetiliselt piire teadlikule keelemuutusele, kui me ei võta arvesse bioloogilistest teguritest tingitud piiranguid. Samuti pole meil mingeid tegelikke tõendeid, et teatud tüüpi tahtlikud keelemuutused on võimatud. Sihilike keelemuutuste 
teostumise võimalused erinevad eri keelekogukondades ja ajastutel, sõltudes mitmesugustest psühholoogilistest, sotsiaalsetest, kultuurilistest ja muudest teguritest" (Tauli 1974: 73).

Pole kahtlust, et Tauli hinnang tahtlike keelemuutuste võimalikkusele, milles ta on oma kaasaegsetest nii erineval seisukohal, põhineb kogemusel Aaviku keeleuuendusega. Oma kokkuvõttes Aaviku keeleuuenduse kohta märgib Tauli (1983: 325): „Aaviku keeleuuendus tõestas vaieldamatult, et üksikisik saab teadlikult mõjutada keelt, isegi suurel määral. Aaviku uuendused tõendavad, et keeles ei ole valdkonda, mida ei saaks tahtlikult muuta. Tema [uuendused] tõendavad, et inimene võib vabalt muuta, asendada ja konstrueerida mitte ainult lekseeme, kuid ka grammatilisi morfeeme, ning et sellised uuendused leiavad keelekogukonna poolt vastuvõttu."

\section{Keelemuutuse piirid}

Eelneva põhjal võib öelda, et Valter Tauli ja Sarah Thomasoni seisukohad on Aaviku keeleuuenduse olemust arvestades tahtliku keelemuutuse olemuse mõistmisel tõele ilmselt kõige lähemal. Samas ei pruugi asjaolu, et tahtlikke keelemuutusi on esinenud keele kõigil tasandeil, tähendada, et tõesti kõik, mida inimene võib välja öelda, võib saada keelemuutuseks. Päris kõik võimalikud keelevääratused ei saa kindlasti keelemuutuseks, olgu tegu siis isetekkelise või tahtliku keelemuutusega. Osa neist jääb muutusena realiseerumata psühholoogilistel, kultuurilistel ja sotsiaalsetel põhjustel, mida Tauli ja Thomason mainivad. Käesoleva artikli seisukohalt on huvipakkuv see, kas osa uuendusi jääb realiseerumata ka seetõttu, et tegemist ei ole keele ehituse seisukohalt konkurentsivõimelise muutusekandidaadiga. Kui osa mõeldavatest muutustest jääb toimumata seetõttu, et nad ei sobi keele ehitusega üldiselt või selle konkreetse keele ehitusega, siis saab siiski väita, et osa keelemuutusi on oma olemuselt võimatud.

Tegureid, mis keelemuutuse toimumist võivad mõjutada, on kirjanduses esile toodud üsna mitmeid. Hea ülevaate nendest annavad Mati Erelt ja Helle Metslang (1998): uuendust soodustab põhinemine keeles juba olemasoleval materjalil; struktuuriline sobivus olemasolevate süntaktiliste ja morfoloogiliste mallidega; lai potentsiaalne kasutusala; ning vastavus universaalsetele ja keelesisestele tendentsidele. Samas on keelemuutuse võimalikkust määravaid tegureid suhteliselt keeruline uurida sotsiaalsete, 
ajalooliste demograafiliste ja kultuuriliste taustatingimuste erinevuse tõttu eri keeltes eri aegadel. Pole ju kerge otsustada, kas muutust ei toimunud seepärast, et selline konstruktsioon rikuks mõnd üldist keelepõhimõtet, või seetõttu, et selle uuenduse algatajatel polnud lihtsalt piisavalt prestiiži, et muutus oleks populaarseks saanud, või jäi muutus toimumata lihtsalt juhuse tõttu. Erinevalt tavalisest keelemuutusest on keeleuuenduse puhul kindlalt teada, et üht või teist muutust üritati keelde juurutada, ja enamasti on ka kirjalikke allikaid, et kontrollida, kuidas uuendus vastu võeti ja kuidas see levis.

Järgnevas arutelus keelemuutuse olemuse üle lähtun Royal Skouseni (1989) hüpoteesist, et keel on analoogiapõhine süsteem, millest tuleneb, et ka keelemuutuse aluseks on analoogia (Ehala 2011). Royal Skousen (1989) seab kahtluse alla traditsioonilise strukturalistliku seisukoha, et keel on reeglisüsteem, sest selline lähenemine keelele tekitab rea põhimõttelisi probleeme. Näiteks reeglipõhine süsteem suudab eristada kindlate piiridega kategoorilist keelekasutust, reeglipõhiseid ja erandlikke vorme. Samas on keel täis sellist varieerumist, mida ei saa reegli ja erandi dihhotoomia abil seletada - selline varieerumine kuulub reeglipõhises süsteemis vea kategooriasse. Näiteks vormid noade ja õlu näidetes täitsa uus noade komplekt ja võtan ühe ôlu ei mahu reeglipõhisesse eesti keele grammatikasse, sest reeglite kohaselt peaks õiged vormid nendes kontekstides olema nugade ja ôlle. Samas on vormid noade ja õlu keeles täiesti olemas, selles võib igaüks Google'is veenduda. Põhimõtteliselt ei ole traditsiooniline grammatika võimeline sellist varieerumist kirjeldama, võimalik oleks see Labovi stiilis variaablusreeglite abil (vt Labov 1972; Cedergren, Sankoff 1974), mis arvestavad iga reegli puhul selle esinemise tõenäosusega.

Royal Skousen (1989) põhjendab veenvalt, et analoogiapõhine lähenemine suudab edukalt modelleerida reeglipõhist kasutust ja samas seletada ka hälbeid sellest. Kui strukturalismis selgitavad reeglid keelelist käitumist, siis analoogilisel modelleerimisel tekitab pidevalt muutuv keelekorpus analoogiarühmad, mis mõjutavad järgmiste lausungite ehitust. Kui traditsionaalse strukturalistliku grammatika puhul on keeleliste võimaluste väli jagatud diskreetseteks osadeks reeglite abil, siis analoogiapõhise lähenemise korral on keeleliste võimaluste väli atomistlik, st puuduvad diskreetsed piirid võimaluste vahel. Kui traditsioonilise grammatikapõhise lähenemise korral eeldab keelekasutus lausungi moodustamiseks kohase reegli valimist, siis analoogiapõhisel lähenemisel vajab keelekasutus 
kohast näidet, mille analoogial lausung moodustada. Seega grammatikapõhise lähenemise korral on keelekasutus keelekirjelduse ehk grammatika funktsioon, aga analoogiapõhise lähenemise korral on kasutus ise kirjeldus, st grammatikat kui üldistust ei ole, on ainult eeskujuks olevad kasutusjuhud. Grammatikapõhine lähenemine tugineb reeglitele ja toodab selle alusel reeglipõhist kasutust, analoogiapõhises lähenemises pole ühtegi reeglit, kuid keelekasutus näib sellegipoolest reeglipõhine, sest iga varasema näite tõenäosus olla aluseks järgmisele keelekasutusjuhtumile on nende kahe juhtumi sarnasuse eksponentsiaalne funktsioon selles kindlas kasutuskontekstis. Näiteks tõenäosus, kas inglise keele määramatu artikkel esineb mingis kindlas kontekstis kujul $a$ või $a$, oleneb mõlema variandi sarnasusest samas kontekstis varem esinenud artikli variandiga ruudus. Oletame, et meid huvitavas kontekstis on varem esinenud määramatu artikli variant $a$. Uue kasutusjuhtumi puhul oleks variandi $a$ sarnasus varasemaga täielik ehk 1 ja $1^{2}$ on 1 , variandi an sarnasus variandiga $a$ on aga vaid osaline ehk 0,5 , aga $0,5^{2}$ on kõigest 0,25 . Nii taastoodab varem esinenud variant enesesarnast oluliselt suurema tõenäosusega, kui on tõenäosus, et uus kasutusjuht erineb varasemast. Praktikas täheldamegi seda kui reeglipärast käitumist. Samas on ka n-ö osaliselt vigasel vormil mingi tõenäosus saada moodustatud.

Seega, kui kasutada traditsioonilist terminoloogiat, siis iga grammatiline konstruktsioon, muutemall, reeglipära, erandrühm või supletiivne üksus on aluseks analoogiaprotsessile, ainult et igaühe tõenäosus sattuda uue lausungi analoogiaaluseks on olulisel määral erinev. Samas tuleb arvestada, et iga mall või reeglipära, mida kirjeldab traditsiooniline grammatika, on tegelikult väga paljude juhtude üldistus. Need juhud on ainult osaliselt sarnased, st iga malli sees on rida väiksemaid malle, väiksema malli sees omakorda väiksemaid alltüüpe, kuni lõpuks on iga süsteemi kuuluv üksus, näiteks sõna, millegi poolest erinev mõnest teisest, mis samuti kuulub sellesse alltüüpi. Seega iga keeleline üksus moodustab tüübi, kuhu ta kuulub üksi, ja seejärel veidi suurema tüübi, kuhu ta kuulub koos oma kõige sarnasema naabriga jne. Seega võib öelda, et kõik mallid on oma olemuselt fraktalilaadse loomuga, sisaldades sarnase malli kordumist üha kitsamas mastaabis, kusjuures kõik need mallid on millegi poolest teineteisega sarnased ja millegi poolest erinevad. Uutel kasutusjuhtudel on erinev tõenäosus saada moodustatud ühe või teise analoogia põhjal: n-ö suured mallid on tõenäolisemad eeskujud uutele vormidele kui väikesed, 
aga kahe üksuse väga suur sarnasus võib tõenäosust mõjutada ka nii, et mõningal juhul võib erand tekitada endasarnast hoolimata sellest, et üldine seaduspära eeldaks mingi teise kasutusjuhu realiseerumist.

Sellest põhimõttest lähtudes on võimalik tuletada ka hüpotees keelemuutuse piiride kohta: keelemuutus x, mille tulemusel tekiks keelde konstruktsioon $\mathrm{X}$, on võimatu, kui selles keeles ei ole ühtegi konstruktsiooni $\mathrm{Y}$, millel oleks kas või osaline analoogiasarnasus konstruktsiooniga X. Teiste sõnadega, kui keelemuutuse kandidaadile pole võimalik leida keelest analoogiat, siis on tegu võimatu keelemuutusega. Järgnevalt püüan seda hüpoteesi Aaviku keeleuuenduse näitel kontrollida.

\section{Aaviku edukas eksperiment}

Aaviku keeleuuendus on kahtlemata üks ulatuslikemaist sellelaadseist ettevõtmisist maailmas. Kui tavaliselt on uuendused piirdunud vaid uute sõnade välmimisega, siis Aaviku ettepanekud on läinud sellest palju kaugemale. Aavik ei püüdnud mitte ainult keeleuuenduse kurvi lõpmatuseni tõmmata, vaid ka selle strukturaalseid võimalusi proovile panna. Tema oma sõnul ,ei pea mitte üksi võima leksikoni puudutada, vaid ka süntaksi ja morfoloogia kallale tungida. Jah, peab tohtima mitte ainult uusi sõnu luua, vaid peab lubatav olema ka uusi grammatikavorme, enneolemata konstruktsioone, uusi tuletuslikke ja flektsionaalseid lõppusid moodustada. Ka see on tarviline" (Aavik 1924: 114). Peab tunnistama, et Aavikut on selles ürituses saatnud arvestatav edu. Tauli (1983) andmeil on Aaviku ettepanekuist ligi poole - 56st 28 - eesti keele normeerivad sõnaraamatud ja grammatikad vastu võtnud. Olgu allpool väike ülevaade nendest ettepanekutest koos hinnanguga sellele, kuivõrd Aaviku uuenduste edu või ebaedu võib põhjendada analoogiabaasi olemasoluga.

Sõnavara rikastati keeleuuenduse käigus üle 800 uue sõnaga. Aavik ise lõi neist paljud ja umbes 16 on igapäevases kasutuses. Oleks huvitav analüüsida keeleuuenduse sõnavaraettepanekuid analoogiahüpoteesi põhjal. On ju sõnavara kõige vähem struktureeritud valdkond keeles ja esmapilgul võib tekkida küsimus, et kuidas analoogiat üldse kasutada, kuid kindlasti saab arvestada eesti keele silbistruktuuri seaduspärade ja fonotaktiliste piirangutega, samuti muutemalli loomulikkusega, mis vähemalt teatud määral toetavad või takistavad uue sõna kasutuselevõttu olenevalt selle sõna häälikulisest koostisest. 
Eesti kirjakeele käändsõnade morfoloogiasse tõi Aavik kõigepealt lühikese vokaalivaheldusel põhineva mitmuse, mis polnud täiesti uus uuendus, vaid keeleajaloolise $i$-mitmuse edasiarendus ja kirjakeelde juurutamine, sest $i$-mitmus esines XX sajandi alguses vaid Lõuna-Eesti murretes ja vähemal määral ka rannikumurdes (vt Rätsep 1979). Aavik ei olnud esimene, kes ajaloolisel $i$-mitmusel põhinevat vokaalimitmust kirjakeelde sobivuse seisukohalt kaalus. Näiteks Jakob Hurt, Karl August Hermann, Harald Põld ja Hans Einer - kõik märkisid vokaalimitmuse võimalust oma grammatikates ja kirjutistes, kuid sellegi poolest laienes XIX sajandi lõpul ja XX sajandi algul hoopis $t$-mitmus, nii et vokaalimitmus oli ununenud ja esines vaid kivistunud väljendeis (Raag 1998). Kuigi vokaalimitmuse puhul on tegu morfoloogiat sügavalt puudutava süsteemse muutusega, toetas selle juurdumist analoogiabaasi olemasolu Lõuna-Eesti murretes. Arvestades, et XX sajandi esimese poole haritlaskonna enamus oli Lõuna-Eesti juurtega, oli uuenduse omasus nende jaoks kindlasti üks edu tagatisi. Samad põhjendused kehtivad suurel määral ka mitmuse lühikese osastava ja ainsuse lühikese sisseütleva edu seletamisel.

Sünteetiline ülivõrre on ilmselt üks Aaviku keeleuuenduse kroonijuveele, sest esiteks on tegu eesti keele jaoks tõeliselt uudse võimalusega ja teiseks on uuendus muutunud eesti kirjakeele osaks, mida kasutatakse hoolimata reeglite keerukusest ja kogu konstruktsiooni vastuolust keeletüpoloogiliste seaduspäradega. Tüpoloogilised seaduspärad morfoloogias kinnitavad, et mida sagedasema vormiga on tegu, seda keerukam võib olla tema morfoloogiline moodustusviis - näiteks supletiivsed tüved esinevad ainult väga sagedastes lekseemides, nagu olema ja minema. Flektiivne vormimoodustus esineb suure sagedusega vormides (eesti keeles omastav, osastav ja lühike sisseütlev), reeglipärasem ja lihtsam aglutinatiivne või analüütiline vormimoodustus aga väiksema sagedusega vormides. Sünteetiline ülivõrre rikub seda seaduspära olulisel määral on ju ülivõrre mitu korda väiksema sagedusega kui keskvõrre, samas on keskvõrde aglutinatiivne moodustamine lihtsam ja reeglipärasem kui flektiivse moodustusviisiga lühike ülivõrre. Seega võiks öelda, et lühike ülivõrre rikub universaalseid keeletüpoloogilisi seaduspärasid ja peaks seetõttu olema võimatu või vähemasti ebatõenäoline muutus, tegelikkus aga tõestab vastupidist.

Seletuse sellele kõrvalekaldele pakub loomuliku morfoloogia teooria (Mayerthaler 1981; Wurzel 1989). Loomuliku morfoloogia teooria seletab, 
miks teatud muutused on keeltes sagedasemad kui teised ja miks teatud konstruktsioonid on tüpoloogiliselt sagedasemad kui teised. Põhjus on selles, et keeled püüdlevad loomuliku oleku poole ja see loomulik olek võib olla kahesugune: universaalne loomulikkus, mis põhineb üldistel inimkeelele omastel kognitiivsetel eelistustel, ja süsteemisisene loomulikkus, mis ilmneb suurte produktiivsete mallide kasvus väikeste ja ebareeglipäraste mallide arvel iga konkreetse keele sees. Ülalkirjeldatud üldine seaduspära, et sagedasemad vormid võimaldavad keerulisemat morfoloogiat, on universaalse loomulikkuse väljendus - inimese kognitiivsed võimed lihtsalt eelistavad sellist asjade korrastuse viisi. Süsteemisisese loomulikkuse puhul on aga tegemist süsteemis olevate mallide analoogiasurvega uutele mallidele. Loomuliku morfoloogia teooria kohaselt on universaalne ja süsteemisisene loomulikkus teineteisest sõltumatud ning võivad keele ajaloolises arengus olla isegi vastandliku suunaga, st kui keeles on mingi tugev mall, mis ei ole universaalses mõttes loomulik, siis võib see sellegipoolest tekitada keelemuutusi, mis suurendavad selle malli levikut selle keele sees. Wolfgang Wurzel (1989) väidab, et konflikti korral nende kahe loomulikkuse vahel jääb alati peale süsteemisisene loomulikkus ehk siis teiste sõnadega: keeles olev tugev analoogia võib alati põhjustada keelde uusi universaalses mõttes ebatüüpilisi vorme. Sama protsess tundub toimuvat ka Aaviku loodud lühikese ülivõrdega. Kuigi universaalses mõttes on tegu ebatõenäolise konstruktsiooniga, mida maailma keeled üldiselt üritavad vältida, siis eesti keele morfoloogia sisemise ehituse seisukohalt see nii ei ole, sest lühikest ülivõrret toetavad juba varem keeles eksisteerinud ja keeleuuenduse käigus kirjakeelde toodud lühike vokaalkujuline mitmuse osastav ja vokaalimitmus. Põhimõtteliselt on lühikese ülivõrde moodustamise reeglid analoogilised vokaalkujulise mitmuse osastava moodustamise reeglitega ja need rakenduvad täpselt samade tüüpide suhtes. Et mitmuse osastav on üsna sage vorm vähemalt ülivõrdega võrreldes, siis toimib see tugeva analoogiaalusena lühikese ülivõrde moodustamisel. Jällegi näeme, et Aaviku uuenduse edu on olulisel määral sõltunud varasema analoogiaaluse olemasolust keeles.

Märkimisväärne on ka Oskar Looritsa (1922) poolt vepsa keele põhjal modelleeritud sünteetilise tingiva kõneviisi lihtmineviku vormi edukas juurdumine. Selle vormi moodustamiseks tuleb liita kõneviisi tunnus $-k s$ nud-kesksõna lühenenud tunnusega vormile, näiteks laulnud $+-k s=$ laulnuks. Vorm on eesti keele jaoks täiesti uudne, sarnast malli kõneviiside 
süsteemis ei ole. Samas on moodustusmehhanism iseenesest vägagi eesti keelele omane. Kesksõna vormi lühendamine ja sellele lõpu liitmine toimib eesti keeles kõigi verbide puhul ja täiesti produktiivselt käändsõnavormide moodustamisel, vrd laulnule, laulnuga, laulnutele, laulnuteta, lauldus, laulduni jne. Loorits (1923) on uuenduse toetuseks märkinud, et eesti murretes võib täheldada tendentsi, et partitsiibid võivad finiidistuda, lubades lühenenud kujule lisada isikulõppe (olnuvad, teinuvad, saanume). Helle Metslang (1991) on toonud esile, et sünteetilise tingiva kõneviisi lihtmineviku kinnistumist toetab ka isomorfismi põhimõte, mille kohaselt lihtmineviku kui absoluutaja isomorfseks väljenduseks sobib sünteetiline vorm paremini kui analüütiline - see tähendab, et see uuendus suurendas keeles universaalse loomulikkuse määra. Seega, tingiva kõneviisi lihtmineviku vormil on eesti keeles ja murretes olemas niihästi morfoloogilised analoogiamallid kui ka üldine surve universaalse loomulikkuse suunas, mistõttu see uuendus langes vastuvõtlikku pinnasesse.

Sama analoogiamall on üsna ilmselt ka sünteetilise vormiuuenduse -maks (tegemaks) edu taga. Verbi infiniitvormide käänamine on eesti keeles produktiivne, sellele ei allu mitte üksnes oleviku ja mineviku isikulised ja umbisikulised kesksõnad (laulev, lauldav, laulnud, lauldud), vaid piiratud ulatuses ka ma- ja da-tegevusnimi (laulmas, laulmast, lauldes - keeleajalooliselt rohkemgi, vt Peegel 1961), ühesõnaga: tegu on fraktalilaadse malliga, millel on laiemaid ja kitsamaid avaldumisvorme, mis kõik kordavad sama mustrit. Sellisesse fraktalipessa paari uue vormi lisamine ainult suurendab süsteemsust, mitte ei riku seda. Seega pole maks-vormi edu väga üllatav. Pigem võiks küsida, mis on teiste sarnaste uuenduste ebaedu taga. Võib-olla ehk malt-uuendus (tegemalt) on veidi vähem põhjendatud eeskätt paronüümilise mast-vormi olemasolu tõttu, kuid sõsarkonstruktsioonid -maga (tegemaga) ja -mani (tegemani) on morfoloogiliselt täiesti keeleomased moodustised, mis aitaks väljendust rikastada. Ellen Uuspõld (1980) on seletanud nende vormide erisugust edu sellega, et erinevalt maks-vormist, mille kasutusvõimalused on väga avarad, saab sõsaruuendusi kasutada vaid teatud verbide rektsiooniliste laienditena, mistõttu nad pole suutnud end õigustada süntaktilis-stilistiliselt ega semantiliselt. Niisiis, kõigi edukate morfoloogiliste keeleuuenduste puhul saab rääkida tugevate analoogiamallide olemasolust, mis on uuendusi toetanud, ja ilmselt ka funktsionaalsest sobivusest. 


\section{Aaviku läbikukkumised}

Edu kõrval tabas Aavikut ka läbikukkumisi. Kui osa neist uuendustest võiks ehk olemaski olla, nagu tegemaga ja tegemani, sest nad on keeleomased ja nende läbikukkumine jäi ilmselt vähese levitamise taha, siis teine osa läbikukkunud uuendusi annab alust väitele, et need on põhimõtteliselt midagi eesti keeles võimatut, kuna neil puudub toetav analoogiamall.

Morfoloogias on heaks näiteks nue- ja tue-gerundiivid (teinue $=$ olles teinud; möödutue = kui ollakse möödutud). Kuigi need sünteetilised vormid on loodud sama morfoloogilise analoogiamalli alusel nagu ka edukaks osutunud teinuks, ei tulene -nue ja -tue läbikukkumine kindlasti mitte vähesest propagandast, vaid sellest, et nendel vormidel puudub fonoloogiline analoogiamall. Mati Hint (2012) esitab sellele veenva põhjenduse - eesti keeles ei lõpe omasõna järgsilp diftongiga, isegi mitte morfoloogilise protsessi tagajärjel. Eesti keele järgsilbi fonoloogia on üldse väga rangete piirangutega: diftong on võimalik vaid juhul, kui tegu on kaasrõhulise silbiga, diftongi järelkomponent on $-i$ ja silp on kas kinnine või ei ole viimane, näiteks aastaid, aastaile. Vormid teinue ja möödutue rikuvad neid seaduspärasid ulatuslikult: diftong on sõnalõpuline ning järelkomponent pole $-i$. Sellised vormid on eesti keeles põhimõtteliselt võimatud. Käesolev näide on oluline sellegi poolest, et ilmestab, kuidas erinevad analoogiamallid ja nende puudumine keeles omavahel koostoimet avaldavad, muutes mõne vormi keelde tuleku tõenäoliseks (teinuks), teiste tuleku aga sama hästi kui võimatuks (teinue). Nii on meil tegu väga hea näitepaariga ilmestamaks hüpoteesi, et keelemuutus põhineb analoogial.

Viimaseks vaatlen Aaviku grandioosset läbikukkumist, kui nii võib öelda - no-genitiivi. Olen sama muutust vaadelnud varem süsteemiteoreetilise vaatenurga alt (Ehala 1996a, 1999a), käesolev käsitlus põhineb olulisel määral varasematel, uudne on muutuse võimalikkuse sidumine analoogiamalli olemasolu või puudumisega.

no-genitiiv on eessõnaline tarind, millega saab väljendada omastavalist suhet. Eesti keeles väljendatakse seda suhet tavaliselt omastavas käändes oleva laiendiga, mis alati eelneb peasõnale, nagu omastavas käändes olev venna eelneb peasõnale raamat näites venna raamat. Aaviku uuenduse järgi võiks omastavat käänet väljendada ka eessõnaga no. Seega siis venna asemel no vend. Lisaks peaks no-genitiiv järgnema peasõnale, mis annaks 
venna raamatu asemel raamat no vend. Esmapilgul tundub, et sellel uuendusel ei ole erilist mõtet, sest olemasolev genitiiv on palju ladusam. no-genitiivi eelised aga tulevad esile lauseis, kus omastavaline laiend on pikem või keerukama struktuuriga. Näiteks juhul kui mitme omastavalise laiendiga lauses ühte laiendit laiendab omakorda kõrvallause, pole võimalik konteksti tundmata aru saada, millise laiendi juurde kõrvallause kuulub. Aavik (1924: 23) toob näiteks lause ta sõbra tütre mehe maja, kes linnas elab. Siin pole võimalik aru saada, kas linnas elab sõber, selle tütar või viimase mees. Teiseks eesti keele omastava puuduseks peab Aavik seda, et keerukate omastavaliste laienditega konstruktsioonis, nagu näiteks ylevuse ja sõnamängu, kõrge lyyrilise inspiratsiooni ja kahtlase loba, vaevalise ja lapsiku peenutsemise ja jauni ning puhta emotsiooni imelik kokkukõla, pole võimalik enne viimast sõna aru saada, mille kohta kõik need epiteedid käivad. Kõik need hädad tulevad Aaviku järgi sellest, et eesti keele omastavaline täiend käib peasõna ees ja mitte järel. Aaviku eesmärk ei olnud asendada olemasolev käändeline genitiiv kogu ulatuses no-genitiiviga, vaid luua ainult olemasoleva kõrvale uus võimalus, mis muudaks eesti keele rikkamaks. Uue konstruktsiooni sissetoomine on kahtlemata kergem ülesanne, kui püüda vana uuega täiesti asendada. Seega võiks no-genitiiv eesti keelt arvestatavalt paindlikumaks teha, kui ta kasutusel oleks.

Tundub, et Aavik ise pidas no-genitiivi üheks oma olulisimaist eeteist. Ta kirjutab: „Eesti kirjakeelne stiil aga, selle asjaolu läbi, et ta genetiivifunktsiooni võib tahtmist mööda väljendada sõna ette või sõna järele paigutet atribuudiga, omandaks painduvuse, mida ei oma ükski suur kultuurkeelgi; eesti lause saaks ses suhtes painduvaimaks maailmas ja eriti kohaseks rangesti loogilises joonistuses esitama keerulisi ja tihedasti kokkusurut mõtterühmi ja agglomeraate, mida ta kerge vaevaga võib paisata lause ühest äärest teise. Eesti keel saaks seeläbi teataval määral kõige kohasemaks ja mõnusamaks teadusliku mõtte väljendajaks! See oleks üleolek, mille saavutamiseks maksaks keele kallal katsuda nii ennekuulmata operatsioone. [---] Seesugune präpositsionaalne genetiivi väljendus .. tingimata tuleb meil tarvitusele võtta, kui eesti keelele tahetakse anda üks ainulaadne painduvus" (Aavik 1924: 126). Arvestades Aaviku pühendumust ja no-genitiivi eeliseid keerukate genitiivtarindite struktureerimisel, võiks eeldada, et see uuendus on samuti leidnud eesti keeles endale tagasihoidliku, kuid vajaliku niši. Paraku aga läks teisiti 
ja tegemist on Aaviku ühe edutuma uuendusega. Olen väitnud ka varem (Ehala 1999a, 1999b), et läbikukkumise põhjus sellel juhul ei tulene vähesest propagandast, vaid pigem on tegu eesti keelde sobimatu või lausa võimatu konstruktsiooniga.

Tuginen oma väidetes sõnajärjetüpoloogia uuringu tulemustele. Tegemist on üsna hästi uuritud valdkonnaga. On üldiselt teada (vt Hawkins 1983), et keeled kipuvad sõnajärje puhul eelistama kahte võimalust. Esimene võimalus on, et peasõna eelneb laiendile, seega siis postpositsioone kasutavas keeles nagu eesti keelgi oleks harmooniline sõnajärg selline, kus omadussõna ja omastavaline laiend eelnevad nimisõnast peasõnale, näiteks kirju koer ja venna koer. Sellise keele sõnajärg oleks siis Post ja AdjN ja GenN. Teistes keeltes on eessõnad ning omadussõnaline ja omastavaline laiend järgnevad oma peasõnale (Prep ja NAdj ja NGen), nagu hispaania keeles un hombre mexicano 'Mehhiko mees' ja madre de la estudiante 'üliõpilase ema'. Loomulikult esineb ka vahepealseid tüüpe, milles osa peasõnu eelneb laienditele ja osa järgneb, ning esineb keeli, kus mõnel puhul on võimalik kahesugune sõnajärg (nagu tegelikult ka hispaania keeles).

Kui vaadata Aaviku no-genitiivi uuendust, siis oleks see tüpoloogiliste seaduspäradega selles osas vastuolus, et keeli, mis kasutaks postpositsioone ja kus oleks samal ajal AdjN- ja NGen-sõnajärg, ei paista maailmas olevat (Hawkins 1983). Seega tundub, et mainitud kombinatsioon ei ole tüpoloogiliselt loomulik. Samas ei ole tüpoloogiline loomulikkus kuigi tugev argument muutuse vastu, kui keele sees olevad analoogiamallid tema levikut toetavad (nagu oli lühikese ülivõrdega). Pealegi ei soovinud Aavik olemasolevat sõnajärge vahetada, vaid lihtsalt luua ühe uue võimaluse. Selline nähtus, kus mingi sõnajärje parameetri puhul esineb kaks paralleelset võimalust, on maailma keeltes väga sage. Ka eesti keeles on tagasõnade kõrval eessõnu, hispaania keeles võib NAdj- ja NGen-sõnajärje kõrval esineda ka vastupidist sõnajärge ja see on omane ka inglise keelele, võrreldagu brother's book ja the Queen of England. Ka eesti keeles võib seda täheldada omadussõnade poeetilise kasutuse puhul, näiteks meri sinine ja taevas pilvine. Kui maailma keeled sellist varieerumist võimaldavad, siis ei peaks ju no-uuenduse juurutamine olema võimatu.

Tuleb aga märkida, et ka dubleerimine, nagu seda nähtust kutsutakse, ei saa esineda, kuidas juhtub, vaid ainult teatud seaduspärasustele alludes. Et sellest mingit ülevaadet saada, tuleb vaatluse alla võtta peasõna ja laiendi 
järjekord ka arvsõnade ja näitavate asesõnade puhul. Nii näiteks jagunevad tagasõnalised keeled sellise tüpoloogia puhul viide klassi.

1) $\operatorname{AdjN}$ ja DemN ja NumN ja GenN ja Post

2) NAdj ja DemN ja NumN ja GenN ja Post

3) NAdj ja NDem ja NumN ja GenN ja Post

4) NAdj ja NDem ja NNum ja GenN ja Post

5) NAdj ja NDem ja NNum ja NGen ja Post

Kõik need viis tüüpi esinevad maailma keeltes, võimatuid kombinatsioone siin ei ole. Esitatud tüpoloogias on seaduspära, et kui keeles toimub muutus tagasõna poolt määratud sõnajärjes (laiend - peasõna), siis esimene, mis oma positsiooni muudab või varieerumist lubab, on omadussõna (tüüp 2). Niisiis, tüübis 1 saab muutuda ainult adjektiivi sõnajärg, kuid sellele peab eelnema dubleerimise periood. Tüübis 2 , kus adjektiivi sõnajärg juba kaassõna omast erineb, saab dubleerimine võimalikuks näitava asesõna puhul; tüübis 3 võib dubleerimine tekkida arvsõna puhul ja nii edasi. Samas on Hawkinsi (1983) järgi selline olukord võimatu, kus omadussõna eelneb nimisõnale rangelt, lubamata alternatiivset sõnajärge, aga näitav asesõna eelneb peasõnale (tüüp NAdj ja NDem ja NumN ja GenN ja Post). Tegu on niisiis teatavat laadi hierarhiaga, mis määrab, millised olekud mingi keele jaoks avatud on ehk teisisõnu, millised muutused on sõnajärje parameetrite puhul võimalikud.

Kuna eesti keel kuulub tüüpi 2, st eesti keeles on võimalik lonkav konn ja teatud juhtudel ka konn lonkav, kuid mitte konn see, konn esimene ja konn minu või konn no mina, siis ei ole eesti keeles Aaviku soovitatud uuendus võimalik, sest sellel lihtsalt puudub kohane analoogia. Või veidi täpsemalt - analoogia, mida pakub konstruktsioon konn roheline, on liiga nõrk selleks, et vastu seista palju tugevamale analoogiamallile, mis kinnitab, et laiend käib nimisõna ees. Vaid siis, kui Aavik oleks ette võtnud hiigeltöö ja muutnud eesti keele sõnajärje nii omadussõna, näitava asesõna kui ka arvsõna puhul, alles siis oleks tal võimalik olnud eesti keelde no-genitiivi sisse tuua. Oleks Aavik seda teadnud, st oleks keeletüpoloogilised uurimused olnud saadaval juba eelmise sajandi alguses, ehk oleks ta siis natuke oma energiat teistele asjadele säästnud ja no-genitiivi mõttest loobunud.

Seega eesti sõnajärje analoogiamallid ei toeta NGen-sõnajärge ja see on üksi piisav põhjus, miks see uuendus pole eesti keeles võimalik. Kuid 
no-genitiivi hädad sellega veel ei lõpe. Tegemist on eessõnakonstruktsiooniga ja kuigi eesti keel kasutab ka eessõnu, on tüüpiline mall tagasõnaline. Seega uue eessõna sissetoomiseks on eesti keeles vähem analoogiaeeldusi kui uue tagasõna tulekuks. Samuti nõuavad kaassõnad eesti keeles valdavalt genitiivi ja mõningad eessõnad ka partitiivi. no-genitiiv oli aga Aavikul planeeritud nõudma oma laiendilt nominatiivi $(1,2)$ (Aavik 1936: 421).

(1) Ta oli valmis seda tegema tingimusel no täieline järeleandmine temale teie poolt selles küsimuses

(2) see oli viis no üks neist rapsoodiaist, mida olin kuulnud

Nimetavalise laiendi jaoks puudub aga eesti keele eessõnade hulgas analoogia täiesti ja tagasõnade hulgas on vaid üks marginaalne eeskuju päev läbi. Seega, peale sõnajärjelise eeskuju puudumise iseloomustab no-genitiivi ka sobiva kaassõna rektsioonimalli puudumine. Eeldades, et artikli kolmandas osas esitatud analoogiahüpotees peab paika ja määrab keelemuutuse võimalikkuse, võib üsna kindlalt väita, et no-genitiivi läbikukkumine on tingitud sellest, et see uuendus pole lihtsalt eesti keeles võimalik kohase analoogiabaasi puudumise tõttu.

\section{Kokkuvõte}

Kuigi ajalooline keeleteadus on vanim teaduslik lähenemine keele uurimisele, ei ole keelemuutuse olemusest päris selget arusaamist siiani. See puudutab ka keelemuutuse strukturaalsete piirangute küsimust. Varasemad uurijad on selliste piirangute tähtsust rõhutanud, keelekontaktide uurimisega seoses on viimastel kümnenditel väidetud, et mingeid põhimõttelisi strukturaalseid piiranguid keelemuutustele pole olemas ja põhimõtteliselt võib keeles toimuda mistahes muutusi. Küsimust komplitseerib asjaolu, et keelemuutus pole hetkeline sündmus, mis sõltub ainult põhjuslikkusest, vaid sellel on oma levikujoon, mida omakorda mõjutavad paljud tegurid. Teisisõnu: pole kerge mõista, miks mingi muutus toimub mingis keeles või jääb toimumata.

Põhimõtteliselt võimaldab keeleuuendus analüüsida keelemuutuse piiride küsimust veidi süstemaatilisemalt, sest on teada, milliseid muutusi uuendajad üritasid ellu viia ja milliste puhul neid saatis edu. Kuid ka sellisel juhul on tegu vaid post hoc-seletustega-keeleuuendus ei ole teaduslikult kontrollitud eksperiment. Näiteks maks-vorm jõudis keelde hulga hiljem 
pärast selle esitamist. Keeleuuenduse ajal aga edu tal polnud. Nii me ei tea, millised ebaõnnestunud muutused on tõesti võimatud, millised jäid aga asjaolude halva kokkulangemise tõttu lihtsalt realiseerumata.

Oluline mõjutegur võib olla ka keelekontakt ja kontaktkeele pakutav analoogia. Laialdase kakskeelsuse olukorras võib mõni sage võõrkeelne mall saada keelekasutajaile nii omaseks, et nad hoolimata analoogia puudumisest selle oma keeles omaks võtavad. Sel juhul on aga tegu väga tugeva analoogiamalli olemasoluga kakskeelsete keelekasutajate jaoks.

Nii jäävad ka selles artiklis esile toodud seletused hüpoteetiliseks. Kindlalt väita saab vaid seda, et analoogiamalli olemasolu keeles iseloomustab kõiki vaadeldud edukaid keeleuuendusi, samuti seda, et analoogiamalli puudumine iseloomustab mitut Aaviku ebaõnnestunud keeleuuendust. Ühesõnaga: analoogia puudumine võib olla tunnus, mis määrab keelemuutuse piirid. Samas ei ole esitatud tõestusmaterjal kindlasti piisav, et küsimust lahendatuks pidada. Analoogia roll keelemuutuses vajab põhjalikumat uurimist, et sajandipikkusele vaidlusele võimalike ja võimatute keelemuutuste kohta rohkem selgust saada.

\section{Kirjandus}

Aavik, Johannes 1924. Keeleuuenduse äärmised võimalused. Tartu: Istandik.

Aavik, Johannes 1936. Eesti õigekeelsuse õpik ja grammatika. Tartu: Noor-Eesti Kirjastus.

Carr, Philip 1990. Linguistic Realities. Cambridge: CUP.

Chomsky, Noam, Morris Halle 1968. The Sound Pattern of English. New York: Harper \& Row.

Cedergren, Henrietta, David Sankoff 1974. Variable rules: Performance as a statistical reflection of competence. - Language 50, 333-355. http:// dx.doi.org/10.2307/412441.

Ehala, Martin 1996a. Integreeritud keeleteooria võimalikkusest kaasaegses keeleteaduses II. - Keel ja Kirjandus 6, 375-384; 7, 447-460.

Ehala, Martin 1996b. Self-organization and language change. - Diachronica $13(1), 1-28$.

Ehala, Martin 1999a. no-genitiivi võimalikkusest keeletüpoloogia taustal. Artikleid ja arhivaale II. Koost. Helgi Vihma. (= Keeleuuenduse kirjastik B3.) Tallinn: Johannes Aaviku Selts, 30-34.

Ehala, Martin 1999b. Stable states and impossible changes: the limits of teleological explanation in diachronic linguistics. - Trames 3 (4), 203-214. 
Ehala, Martin 2011. The diffusion of impositional innovations in the Estonian object-marking system. - Diachronica 28 (3), 324-344. http://dx.doi. org/10.1075/dia.28.3.02eha.

Erelt, Mati, Helle Metslang 1998. Oma või võõras? (Muutuv keel.) - Keel ja Kirjandus 10, 657-668.

Hawkins, John A. 1983. Word Order Universals. New York: Academic Press.

Hint, Mati 2012. Hilise Aaviku radikaalne keeleuuendus. - Keel ja Kirjandus 2, $81-102$.

Kulick, Don 1992. Language Shift and Cultural Reproduction: Socialization, Self, and Syncretism in a Papua New Guinean Village. Cambridge: Cambridge University Press.

Laycock, Donald C. 1982. Melanesian linguistic diversity: a Melanesian choice? - Melanesia: Beyond Diversity. Ed. Ron J. May, Hank Nelson. Canberra: Australian National University Press, 33-38.

Labov, William 1972. Sociolinguistic Patterns. Pensylvania: University of Pensylvania Press.

Labov, William 1994. Principles of Linguistic Change. Oxford: Blackwell.

Lightfoot, David 1991. How to Set Parameters: Arguments from Language Change. Cambridge, Massachusetts: MIT Press.

L[oorits], O[skar] 1922. Tingiva ja kaudse kõneviisi minevik. - Eesti Keel 1, $170-173$.

Loorits, Oskar 1923. Eesti keele grammatika. Tartu: Odamees - Carl Sarap.

Mayerthaler, Willi 1981. Morphologishe Natürlichkeit. Wiesbaden: Athenaion.

Metslang, Helle 1991. Ajast ja tema vormist verbitarindeis. - Keel ja Kirjandus 3, 163-168.

Oksaar, Els 1972. Spoken Estonian in Sweden and in the USA: an analysis of bilingual behaviour. - Studies for Einar Haugen. Presented by friends and colleagues. Ed. Evelyn Scherabon Firchow, Kaaren Grimstad, Nils Hasselmo, Wayne A. O’Neil. (= Janua Linguarum. Series Maior 59.) The Hague: de Gruyter, 437-449.

Peegel, Juhan 1961. Eesti regivärsilise rahvalaulu keelest. Tartu: Tartu Riiklik Ülikool.

Popper, Karl R. 1972. Objective Knowledge. Oxford: Clarendon Press.

Raag, Virve 1998. The Effects of Planned Change on Estonian Morphology. (= Studia Uralica Upsaliensia 29.) Uppsala: Universitet Uppsala.

Rätsep, Huno 1979. Eesti keele ajalooline morfoloogia II. Õpivahend eesti filoloogia osakonna üliõpilastele. Tartu Riiklik Ülikool, eesti keele kateeder. Tartu: Tartu Riiklik Ülikool.

Sapir, Edward 1921. Language: An Introduction to the Study of Speech. New York: Harcourt Brace.

Skousen, Royal 1989. Analogical Modeling of Language. Dordrecht: Kluwer. 
Tauli, Valter 1974. The theory of language planning. - Advances in Language Planning. Ed. Joshua A. Fishman. The Hague: de Gruyter, 49-68.

Tauli, Valter 1983. The Estonian language reform. - Language Reform. History and Future. Vol 2. Ed. István Fodor, Claude Hagège. Hamburg: Helmut Buske Verlag, 309-330.

Thomason, Sarah 2007. Language contact and deliberate change. - Journal of Language Contact - THEMA 1, 41-62. http://dx.doi.org/10.1163/ 000000007792548387.

Uuspõld, Ellen 1980. maks-vorm ja teised finaaladverbiaalid. - Keel ja Kirjandus 12, 729-736.

Wurzel, Wolfgang 1989. Inflectional Morphology and Naturalness. Dordrecht: Kluwer. 


\title{
Limits for language renewal and analogy
}

\author{
Martin Ehala
}

The article analyses, on the example of Johannes Aavik's language renewal, the structural limits for intentional language changes and whether the analysis of language renewal can reveal the limits of possible changes in language in general. Traditionally in historical linguistics, an understanding has prevailed that intentional language changes are superficial, and more substantial structural changes cannot be introduced at will. Over the past half-century, this position has been called into question, presenting examples to the contrary. Also, Aavik's language renewal supports the latter view. Based on the model of analogical modelling by Royal Skousen, the article hypothesizes that these changes, for which there is no analogy in the language, are not possible and cannot be introduced. To test the hypothesis, the successful innovations by Aavik and others are analysed. For all successful changes introduced in the course of language renewal, there is a clear and powerful analogical pattern in the Estonian language. The hypothesis is also supported by the fact that some of the failed innovations, such as the -nue and -tue constructions and the no-genitive, lack analogy in Estonian, which can help to explain why they were not successful. Thus, the analysis supports the hypothesis that changes that have no analogy pattern in the language are impossible, but the limited scope of the material analysed does not allow a conclusive answer.

Keywords: language renewal, impossible language changes, analogy

\author{
Martin Ehala \\ eesti ja üldkeeleteaduse instituut \\ Tartu Ülikool \\ Jakobi 2-443 \\ 51014 Tartu \\ martin.ehala@ut.ee
}

